\title{
ミース・ファン・デル・ローエのモンタージュ表現とその特質に関する研究
}

\section{A RESEARCH OF CHARACTERS OF MIES VAN DER ROHE'S MONTAGE}

\author{
岩田章吾*, 足立裕司** \\ Shogo IWATA and Hiroshi ADACHI
}

\begin{abstract}
In this research, we analyzed Mies van der Rohe's montages on following aspects, in order to understand the characters of each montage expression and categorize them on these characters. Montages are analyzed on following 2 aspects, and in order to understand the role of montage, we also analyzed Mies's hand-drawings on same aspects. Because almost all montage was based on the perspective, we mainly research them.
\end{abstract}

1. The character of the projects:

The character of the projects for which montages was drawn was analyzed on its program, site, the year of production, architectural typology, and so on.

2. The character of the montage:

Montages are categorized on the character of them, and we analyze the common character of each category.

(1) The character of the perspective drawing

(2) The character of the montages technique

Keywords : Mies van der Rohe, Montage, Drawing, Modernism ミース・フアン・デル・ローエ、モンタージュ、ドローイング、モダニズム

\section{はじめに}

ルードヴィッヒ・ミース・ファン・デル・ローエ (Ludwig Mies van der Rohe 1886-1969. 以下ミースと記す) は建築家としての出発点 から晚年にいたるまでモンタージュ表現を用いた作品（以下モンタ 一ジュと記す）を数多く作成し、その多くが彼の実施された建築プ ロジェクトと同様に展覽会、作品集において展示、揭載されている。 これらのモンタージュは彼の空閒概念を表出した作品として最も成 功していると評価されており、またミースの空間を「モンタージュ 的」と論じる事例もいくつか見受けられる゙。しかし、ミースの作品 理解においてこれらのモンタージュは全体として言及されることが ほとんどであり、個々のモンタージュの持つ特質の分析は十分に行 われているとはいえないのが現状である。

ミースに関する既往の研究のうち、モンタージュを一つの独立し た表現媒体として分析した研究 ${ }^{3}$ は少なく、主要なものとしては近年 催されたミースの回顧展の図録における、アンドレス・レピック

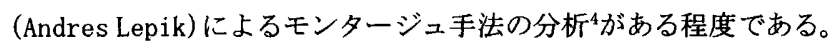
レピックは、モンタージュの分析からミースのセルフ・プロモーシ ョン戦略を読み取ろうとしている。しかし、レピックはドイツ期の モンタージュ、特に初期のビスマルク記念碑とフリードリッヒ街の高 層建築のモンタージュについては詳細な検討を行っているものの、そ
れ以外のモンタージュについては、概括的な分析は行っていない。そ のため、個々のモンタージュの表現手法に注目した本研究はレピック の研究を補完する ${ }^{5}$ のであると考える。なお、本編は次に続く、「ミ 一スのインテリア透視図のモンタージュにみる内外空間の関係に関す る研究」の前段階として位置づけられる。

\section{1 章 研究対象と方法}

ミースのモンタージュにはコラージュやフォトモンタージュなど の呼称がさまざまな研究者によって用いられているが、確定した呼 称は存在しない。本研究では、写真、ベニヤ、紙などの素材を画面 に貼り付けることで作成された作品をモンタージュと総称する。こ れらのモンタージュをさまざまな見地から検討することによって分 類を行い、分類ごとの特質を抽出する。なお本研究ではモンタージ ユに近似する手法として、透視図法によるハンドドローイングを適 宜、比較の対象としている7。

(1) 研究資料

研究資料を現在最も充実したドローイング集であるニューヨーク 近代美術館の『ミース・ファン・デル・ローエ・アーカイブ (Mies van der Rohe Archive) vol.1-20』に主要な作品集 ${ }^{8}$ 加え、これらに揭 載された総数 56 点のモンタージュ ${ }^{9}$ を研究対象とする。なお対象中
$*$ 神戸大学大学院自然科学研究科 大学院生 $\cdot$ 工修

** 神戸大学大学院自然科学研究科 教授・博士(工学)
Graduate Student, Graduate School of Science and Technology, Kobe University, M. Eng.

Prof., Graduate School of Science and Technology, Kobe University, Dr. Eng. 
1947 年の「劇場」における立面図のモンタージュ 2 点と、外部空間 を描いた外構透視図のモンタージュ 2 点以外の 52 点は全て透視図法 による建築のモンタージュであり、本研究の主な研究対象とする。

(2) 研究方法

本研究は以下の二つの特質に注目し、これらの特質からモンター ジュを分類し、モンタージュ表現とそれが採用されたプロジェクト の特質との関係を分析する。

i）モンタージュが作成されたプロジェクトの特質

ここではモンタージュが作成されたプロジェクトの概要（制作 年 ${ }^{10}$ 、立地条件、実施の有無、用途、建築の形態的特質などの 項目）について考察する。また、これらの分析において、モン タージュの位置づけを考察する材料として、ハンドドローイン グにおいても同様の分析を行う。

ii）モタージュ表現の特筫

ここではモンタージュの図法や手法について調查し、共通する 特質を抽出し、下記の 2 項に注目して分析する。

\section{(1)透視図法の特貿}

ミースのモンタージュの図法を分析する。その大半が透視図法 によって描かれているため、対象となる空間の内外の区別、消 点の位置（歩行者の視点で描かれた外観透視図と鳥瞰透視図）、 消点数、透視図としての整合性を検討する。

\section{(2モンタージュ表現の特筫 :}

モンタージュされた素材の種別、素材同士およびモンタージュ 素材とその地となる画面との関係を分析する。

\section{2 章 研究の前提}

個々のモンタージュの分析を行う前に研究の前提として次の二点 を確認する。一つはミースのモンタージュ手法の採用とそれがベル リンダダから影響を受けたものであるという指摘についての検討で あり、もう一つは、モンタージュ手法のドローイングへの適用がミ 一スの意図を反映したものであるかについての検討である。

(1) ミースのモンタージュとベルリンダダとの影勧関係について

ミースのモンタージュ手法の使用を当時交流 ${ }^{11}$ あったベルリン ダダのメンバーからの影響とする指摘が存在する ${ }^{12}$ 。ミースの最初 のモンタージュは1910年のビスマルク記念碑の設計競技のために作 成されている。ただし周辺写真に建築のドローイングを重ね合わせ る手法は 1900 年ごろから開始されており、ミースが最初にモンター ジュを作成した1910年にはすでに建築の領域では一般的な手法であ ったと考えられる ${ }^{13}$ 。一方、ベルリンダダのメンバーが写真を加工 したドローイングを「モンタージュ」「フォトモンタージュ」と名づ け、自らの表現手法としたのは 1916 年から 1918 年の間といわれて いる ${ }^{14}$ 。つまり、写真を操作して作品を作り上げるという技術的側 面だけ見れば、ダダからミースへの影響関係は成立しない。

ベルリンダダのモンタージュの持つ革新性はこのような技術的側 面ではなく、絵画の形式としての革新性であると考えられる。ダダ の作品に限らず、当時の絵画の領域におけるモンタージュ手法の特 質は、断片の非透視図的な配置によるルネッサンス以降の絵画のも つ「イメージの再現」という特質の破壊や、本来の場所から切り取 られた素材を再配置することによる、絵画としての統一性の破壊 ${ }^{15}$ どが指摘されている。しかしミースのモンタージュの大半が透視図
として描かれていることはひとつの顕著な特質といえ、ダダのモン タージュの非透視図的な特質とは合致しない。ただし、ミースのモ ンタージュが従来の透視図のもつ再現的特質の枠内で作成されてい たかについては個別に検討する必要があると考えられる。しかし、 ミースやベルリンダダのメンバーによる言説等もない現時点では、 両者の影響関係の検証は不可能であると考えられる。

(2)モンタージュ手法の適用とミースの意図についての検討

i）ドイッ期におけるモンタージュ手法の採用について

ベルリン期のモンタージュが作成されたプロジェクトの大半が設 計競技であった（表 1 参照)。そのため、これらのモンタージュは要

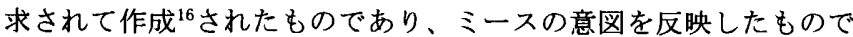
はない可能性が指摘できる。最初にモンタージュ手法が採用された 1910 年のビスマルク記念碑の設計競技案は上位 26 人に選ばれた ${ }^{17}$ も のの、当時のミースがこのモンタージュを展覧会や雑誌などに発表 したという記録は見出せなった ${ }^{18}$ 。一方、フリードリッヒ街の高層 建築のモンタージュは実際には展覧会用に設計競技後に作成された と考えられる19。また、このモンタージュは 1924 年 6 月の『G』3 号に挿絵として採用されている20。アダムビル (1928) とシュッット ガルトのバンクビルディング計画(1928) は設計競技であるが、その モンタージュは 1929 年のアルトゥール・コルン（Arthur Korn）の 『Glas im Bau und als Gebrauchsgegenstand』に揭載されている21。 また、アレキサンダー広場再開発の鳥瞰モンタージュは 1929 年 2 月の『Das Neue Berlin』に発表されている22。1920 年代において、 ミースは自らの建築家としてのイメージを確立するために非常に注

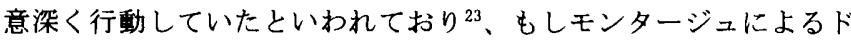
ローイングがミースにとって自らの建築理念を表現する上で望まし い手段でなかったとすれば別途ハンドドローイングを作成していた と考えられる。これらのことからドイツ期においてもミースはモン タージュを表現上の重要な手段として位置づけていたと考えられる。 ii) アメリカ期におけるモンタージュ手法の採用について

アメリカ期においては、モンタージュが設計競技の提出物として 作成されることは無く、その一方で実施を前提としない企画のプロ ジェクトにおいてモンタージュが多く作成されている。ミースがI. I. T. のカリキュラムにおいてモンタージュ手法を建筑イメージの伝達手 段として積極的に活用しており、これを発展させる形で自らのモン タージュを作成していたことがわかっている24。このことから、ア メリカ期においてミースはモンタージュを自らの建築イメージを表 現する適切な表現手段である考えていたと考えられる。

\section{3 章 モンタージュが作成されたプロジェクトの特質}

本章では 1 章の研究方法における「モンタージュが作成されたプ ロジェクトの特質」の検討を行う。

モンタージュとドローイングが作成されたプロジェクト(建築計画) の特質を表 1,2 に抽出した。表 1 の通り 52 点（表中 c ）の透視図モ ンタージュ中 22 点 (表中 $a$ ) が建築を外部から描いたモンタージュ (外 部モンタージュ）であり、30 点(表中 b) が建築の内部空閒を描いた モンタージュ（内観モンタージュ）である。ドイツ期に作成された モンタージュ 15 点は全て外部モンタージュであるが、アメリカ期に 作成された建築透視図モンタージュ37点のうち外部モンタージュは 7 点のみであり、その大半が内観モンタージュという際立った対比 
を見せている。また、ドイツ期の外部モンタージュのうち 14 点が外 観モンタージュであり、鳥瞰モンタージュは 1 点のみである。一方、 アメリカ期においては、外観モンタージュは 1 点のみである。前述 のようにドイツ期のモンタージュの大半が、パブリシティーに利用 されているのに対して、アメリカ期の1点のモンタージュは、作品 集に揭載されていないだけでなく、プロジェクトの存在自体がほと んどの研究書において言及されていない。これらのことからドイツ 期とアメリカ期では、ミースにモンタージュについての何らかの認 識の変化があった推察される。また、外部モンタージュと内観モン タージュがともに作成されたプロジェクトは 24 プロジェクト中、唯 一「コンベンションホール」のみであり、外部モンタージュを作成 されたプロジェクトと、内観モンタージュを作成されたプロジェク トの大半が一致しないことから、内観モンタージュと外部モンター ジュは作成されたプロジェクトの特質が異なる可能性が推察される。

(1) 実施/アンビルド

ミースによる全プロジェクト ${ }^{25} 、 189$ 件中モンタージュが作成され たのは 24 件 (13\%) (建築透視図のモンタージュのみでは 22 件 $(12 \%)$ ) ハンドドローイングが作成されたのは 44 件（23\%）（建築透視図の みでは 37 件 $(20 \%))$ であった。ドイツ期の全 55 プロジェクト（そ のうち 32 件、58\%がアンビルドプロジェクト)中モンタージュが作 成されたのは8件で、すべてアンビルドプロジェクトであった $(100 \%) 。$ アメリカ期の全プロジェクト 134 件 (そのうち 75 件、56\%がアンビ ルドプロジェクト) 中モンタージュが作成されたのは 16 件。この内 11 件がアンビルドプロジェクト $(69 \%)$ である。一方、ハンドドロ ーイングにおいてはドイツ期では作成されたプロジェクト 23 件中

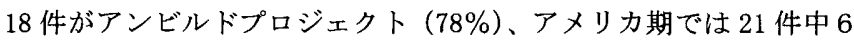
件がアンビルドプロジェクト（29\%）となっている。ドイツ期のモ ンタージュが作成されたプロジェクトがアンビルドプロジェクトで ある比率は、ドイツ期のプロジェクト全体におけるアンビルドプロ ジェクトの比率と比べても際立っている。アメリカ期においても、 モンタージュが作成されたプロジェクトにおけるアンビルドプロジ ェクトの比率は、プロジェクト全体におけるアンビルドプロジェク トの比率に比べるとドイツ期ほどではないがやはり高い。ドイツ期 の比率の高さは前述のようにモンタージュが作成されたプロジェク トの大半が設計競技のプロジェクトであったためであると考えられ る。一方、アメリカ期では、モンタージュが作成されたプロジェク トに設計競技はないが、小都市の美術館や、コンサートホールなど、 企画としての計画の存在がその理由の一部と考えられる。

\section{(2) 立地・用途・建築の特質}

立地や用途に関しては外部 (外観＋鳥瞰)モンタージュと内観モン タージュでは異なる特質が見出せるため以下では個別に分析を行う。

i）外部モンタージュ

外部モンタージュが作成されたプロジェクトは、初期のビスマルク 記念碑を除く全てが都市部（表 1 における都心部と I. I. T. を含む） のプロジェクトである。ドイツ期のモンタージュのうち 6 プロジェ クトは高層建築であり、ドイツ期に計画された高層建築のプロジェ クト 9 件の $67 \%$ を占めている。一方、アメリカ期では外部モンター ジュは 5 プロジェクトで作成されているが、都心部の高層建築のプ ロジェクトは 3 件であり、アメリカ期に計画された高層建築のプロ ジェクト 33 件の $9 \%$ しか占めていない。
表 1：モンタージュが作成されたプロジェクトの特筫 (O印は該当を示す)

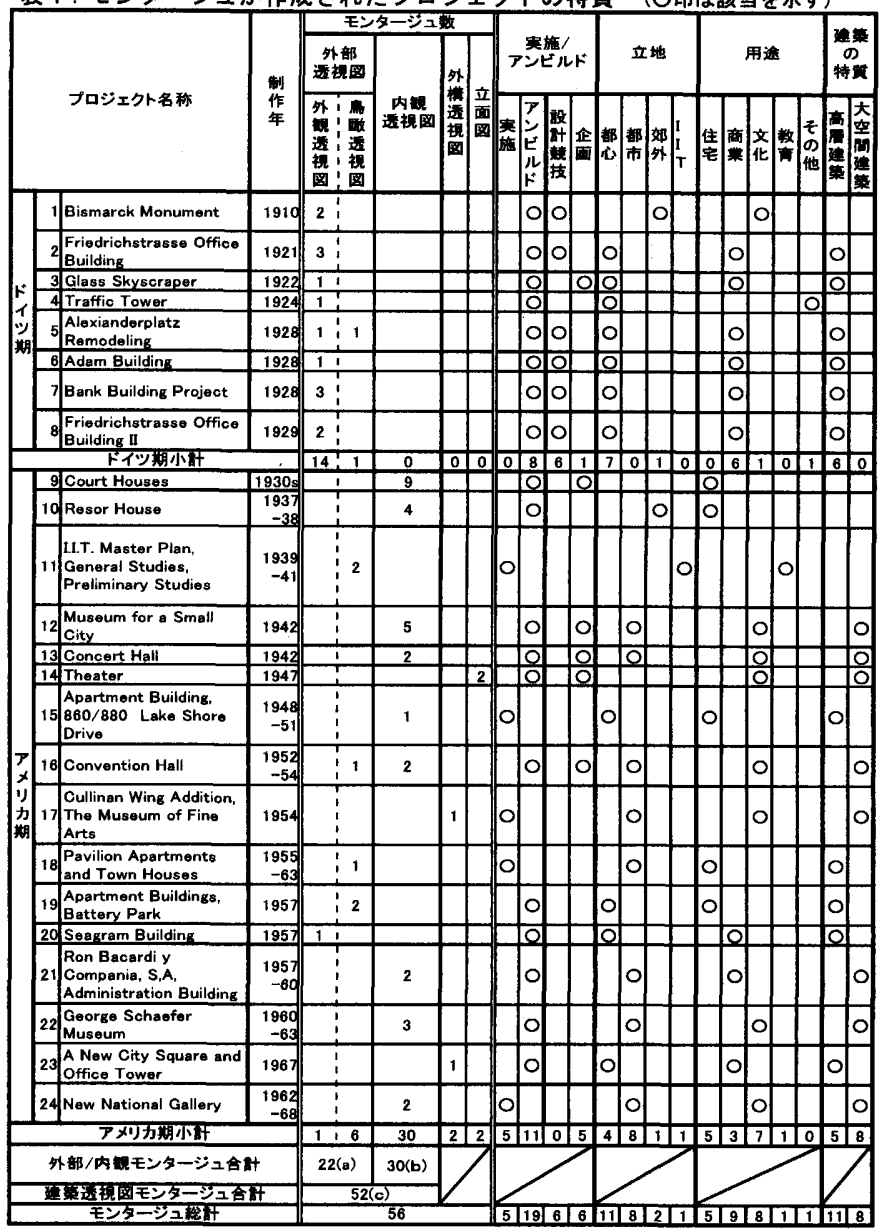

表 2 : モンタージュ、ハンドドローイングが作成されたプロジェクトの特算

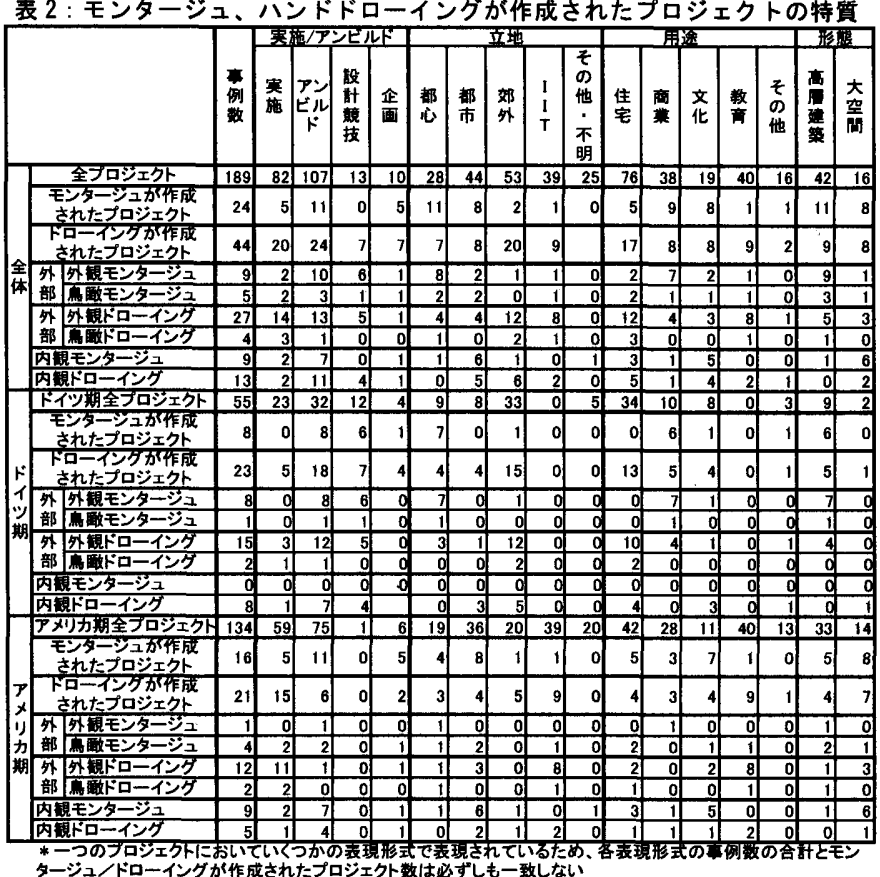

ハンドドローイングにおいては、ドイツ期では外部透視図が描か れているプロジェクトのうち、都心部の高層建築のプロジェクトは 3 プロジェクトのみであり、大半が郊外の住宅（16 件中 10 件）とな っており、モンタージュと補完的関倸を形成している。アメリカ期 では、12 プロジェクトのために外観ドローイングが作成され、2プ 
ロジェクトのために鳥瞰ドローイングが作成されている。外部透視 図が作成されたプロジェクトは全て都心部の規模の大きな建築であ るが、その大半が I. I. T.の建物であり高層建築は 2 件のみである。 ii）内観モンタージュ

内観モンタージュはアメリカ期の 9 件のプロジェクトで作成され ている。その立地、用途ともに多様になっているが、9 件のプロジ ェクトのうち高層建築は 1 件のみである。残りの 8 件は規模の大小 はあっても低層で、そのうち 6 件が大空間建築である。ハンドド口 ーイングによる内部空間の透視図はドイツ期では 8 プロジェクト、 アメリカでは 5 プロジェクトのために作成されている。ドイツ期で は郊外の住宅が半分を占めるがアメリカ期では特定の立地条件、用 途、建築形態といった共通する特質は見出せない。

\section{4 章 外部モンタージュの特質とその变道:}

本章では1章の研究方法における「モンタージュ表現の特䁈」の 外部(外観十鳥瞰)モンタージュにおける検討を行う。

外部モンタージュのプロジェクト概要、透視図形式および、モン タージュ形式の特質を表 3 に抽出した。

(1) モンタージュの特筫

\section{(1)透視図法の特筫}

ドイツ期に作成された外部モンタージュの 15 点のうち 14 点が外 観モンタージュであり、鳥瞰モンタージュはアレキサンダー広場の 再開発計画のための 1 点のみである。一方、アメリカ期においては、 7 点中 6 点が鳥瞰モンタージュで描かれており、外観モンタージュ はシーグラムビルディング・シカゴの 1 点のみである。外部モンタ ージュはすべて、画面の地（背景）は敷地の周辺写真であり、そこ に図として模型写真またはドローイングがモンタージュされている。 敷地の写真は透視図とみた場合、全てが二消点透視図法、3 消点透 視図法の形式をとっている。貼り付けられた素材は、模型写真、ド ローイングのいずれにおいても、背景の写真の空間的枠組みに則っ て二消点透視図法または 3 消点透視図法的に表現されており、一つ の透視図としてその空間表現に曖昧さは見出せない。

(2)モンタージュ表現の特貿

外部モンタージュのモンタージュ表現には作成年に忘じて差異が 見られ、固定した手法は見出せない。作成された 15 点の外部モンタ ージュのうち 8 点を占め、手法的にも一貫している 4 つのプロジェ クト、アレキサンダー広場の再開発計画、アダムビル、バンクビル ディング計画、フリードリッヒ街のオフィスビル II のモンタージュ はわずか 2 年、1928一1929 年の間に作成されているだけである。

ビスマルク記念碑のモンタージュは背景もモンタージュ素材もと もに写真であり、両者がひとつのイメージを形成するように背景の 画面にドローイングを加えるなどの調整を行っていることから、背 景と素材間での表情の違いはそれほど大きなものとはなっていない。

フリードリッヒ街の高層建築は、背景の写真とドローイングの建 築との質感の違いの調整を行っていないものと行っているものが存 在する（図 1)。調整を行っていないモンタージュは初期案と考えら れ、これをべースに周辺街区にドローイングを重㸚たモンタージュ およびハンドドローイングが作成されたと考えられる ${ }^{26}$ 。最終版とさ れるハンドドローイングにおいては初期案にみられた既存の街並み とガラスのカーテンウォールの対比はドローイングにおける明暗の
表 3 : 外部モンタージュの特置

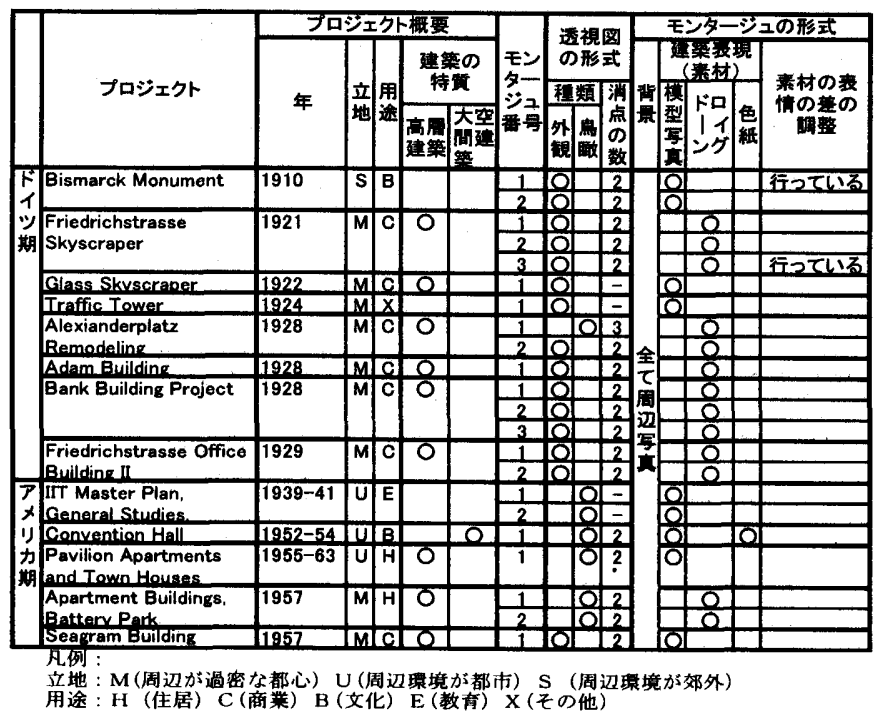

対比に膡き換えられている。その結果、新旧の対比はより強調され る一方で、一つの絵画的表現としての統一性も高められている。

1922-24 年に作成された 2 点の外観モンタージュは背景と素材 の間の表情の差異は調整されていないが、模型写真がモンタージュ されており、背景と素材の表情の差による画面上の効果といったモ ンタージュ表現の特質は弱められている。

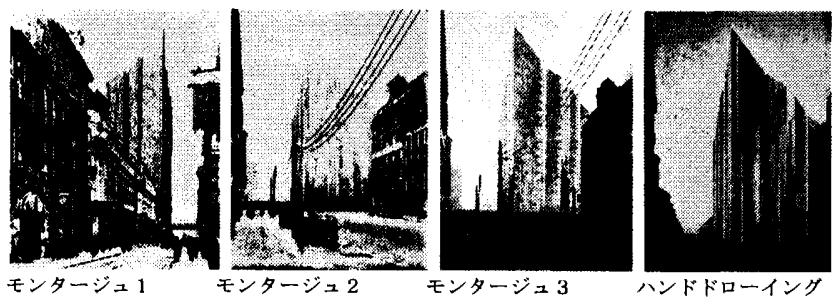

図 1: フリードリッヒ街の高層建築

外部モンタージュにおいて、ほぼ共通の手法によって作成されて いるのは 1928 年一1929 年に作成された 4 つのプロジェクトのため の 7 つの外観モンタージュである(図 2)。これらのモンタージュに 共通する特質はハンドドローイングによるガラスカーテンウォール と街並写真の、デザイン的にも表現の質感においても異なるものの 並置である。このことにより、フリードリッヒ街の高層建築のハン ドドローイングのような明暗に二元化された対比とは異なる対比が 生み出されている。ただし、ミースは建物の外観を質感とスケール 感を与えるように描いているため貼り付けられたドローイングと背 景の間の表現上の差異は透視図としての再現的な特質を摇るがすよ うなものとはなっていない。一方、ドイツ期に唯一作成された、ア レキサンダー広場の鳥瞰モンタージュにおいては、計画された建築 が外観モンタージュ以上に表情のない抽象的なボリュームとして表 現され、敷地はきわめて単純な空白として表現されており、外観モ ンタージュより大きな対比を形成している（図 3）。

1929 年以降、現在確認されている外観モンタージュはアメリカ期 に作成されたシーグラムビルディング・シカゴ27(図 4)のモンタージ ュのみである。このモンタージュは背景写真に模型写真がモンター ジュされており、その表現は周辺と建物の対比を強調するものでは なく、1928 年一 1929 年のモンタージュとは大きく異なっている。 一方、アメリカ期には鳥瞰モンタージュが 6 点作成されているが、 
これらに共通する手法は見出せずアレキサンダー広場の再開発と同 様の抽象化されたボリュームと単純な空白として表現された敷地と いう表現は、アメリカ期では、I.I.T.キャンパスの配置計画(図 6 )と コンベンションセンターの鳥瞰モンタージュに見出せるのみである。

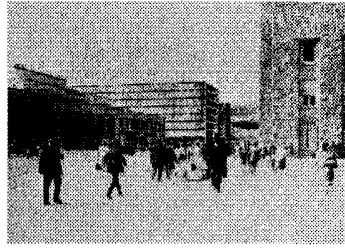

図 2 : バンクピルディング䂥画

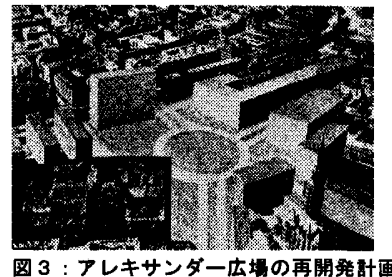

图 3 ：アレキサンダー広堨の再開発計面
(2)考察：モンタージュによって表現される建築と周辺の関係

外部モンタージュの手法は制作年ごとに変化しており、共通する 特質を見出すのは困難である。しかし、全てのモンタージュが写真 を背景としており、モンタージュされた要素は背景の写真が表現す る空間的広がり、スケール感を逸脱するようには配置されていない。 そのため、透視図としての視覚的再現性はある程度維持されている ということができる。

最初に作成されたビスマルク記念碑のモンタージュを除き、モン タージュ手法が採用されるプロジェクトはドイツ期もアメリカ期も その大半は都市部の大規模建築である点は共通している。一方、八 ンドドローイングは、都市部の大規模建築の表現においては、ドイ ツ期では、4プロジェクト(都心部 3 プロジェクト、都市部 1 プロジ エクト)のための 7 点のドローイングが作成されているが、このうち、 周辺の街区が表現されているものは 3 点のみである。また、アメリ カ期では 30 点の外部透視図のドローイングが作成されたが、その うちの 24 点が I.I.T.の施設であり、建物は単独か、I.I.T.内の建物 とともに描かれており、敷地外の街並みは描かれていない。また、 残りのドローイングにおいても周辺の街区が描かれたものはわずか に2 点しか存在しない。このことから、ミースは計画された建築と その周辺の都市との関係を表現する手段として外部モンタージュを 使用していたと考えられる。

計画された建築とその周辺の描き方においてはドイツ期とアメリ 力期では以下のような相違が見出せる。ドイツ期においては外観モ ンタージュで表現された都心部の高層建築は常に全体像としてでは なく、街並みの一部として、つまり周辺建物に切り取られた部分だ けが表現されている(図 2)ことが一つの表現上の特質といえる。一方、 アメリカ期に唯一作成された外観モンタージュにおいて、計画され た建物は外観が周辺建物に切り取られることは無く、街並みから切 り離されて、独立した全体像として表現されている(図 4)。アメリカ 期においてハンドドローイングによって表現された都市部の大規模 な建築の大半が I.I.T.のプロジェクトであり、その表現には敷地外の 周辺建物は表現されていない。また、それ以外の都心部の高層建築 のドローイングにおいても外観モンタージュと同様にその外観が敷 地の周辺建物に切り取られること無く建物の全体像が表現されてい る(図 5)。この表現における変遷は、表現意図の変化以上にミースの 作風の変化や、ドイッとアメリカの都市構造の相違などに由来する と考えられる。しかし、このような外的要因が、アメリカ期では外 部モンタージュが作成されなくなった一因であるならば、ドイツ期 の外部モンタージュの表現である都市の街並みの一部に自らの建築 を組み込むことによる周辺環境との対比的関係の表現がこれらのモ
ンタージュにおける表現意図であったと推察される。

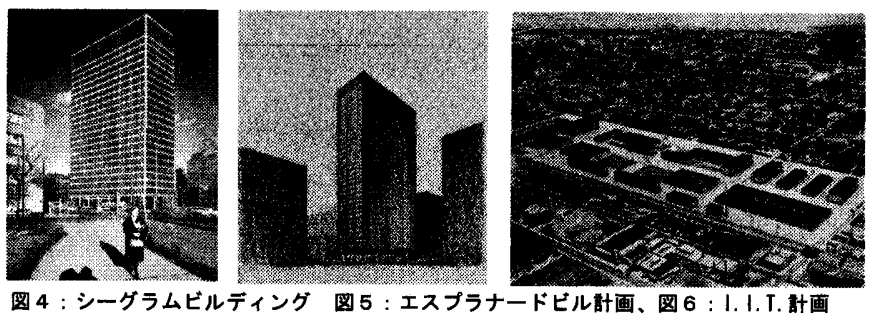

\section{5 章 内钼モンタージュの特質とその変僄}

本章では 1 章の研究方法における「モンタージュ表現の特質」の 内観モンタージュにおける検討を行う。

内観モンタージュの透視図法、モンタージュの形式と作成された プロジェクトの建築の特質を表 4 にリスト化した。また、建築の特 質においては描かれた内部空間の特質をより詳細に分析するために、 ミースの空間の特質に関する論述からキーワードとして、「流動的空 間」「単一空間 (unitary space)」「ユニバーサルスペース」を、空 間の特質に関連する要素として「フリースタンディングウォール」 を抽出した ${ }^{28}$ 。このうち、ユニバーサルスペースはミース理解にお いて重要な概念であるものの、多義的に使用されており空間形態と しては流動的空間、単一空閒などと重なり合う部分もあるためここ ではとりあえず除外し、残りの 3 項目について描かれた内部空間の うち該当する項目をリスト化した。また、内部空間の表現における ドイツ期とアメリカ期の関係を理解するために、表 5 に内観透視図 のハンドドローイングにおける同様の特質についてリスト化した。

内観モンタージュは次に述べるように A, B の二つに分類が可能で ある。つまり、内観モンタージュは内部空間の大きな枠組みを表現 する手法が、無地のイラストレーションボードに描かれた単線によ る透視図による内観モンタージュA と（図 7)、建築写真または模型 写真による内観モンタージュB（図 8) に分類可能である。これは要 素がモンタージュされる画面の「地」(背景)となる部分が無地のイ ラストレーションボードに描かれた単線ドローイングであるか、写 真であるかによる分類である。前者は内観モンタージュの大半を占 める 25 点作成されており、後者は 5 点のみとなっている。この二種 類のモンタージュはいくつかの点において異なる特質を有している ため、それぞれの特質を個別に分析する。

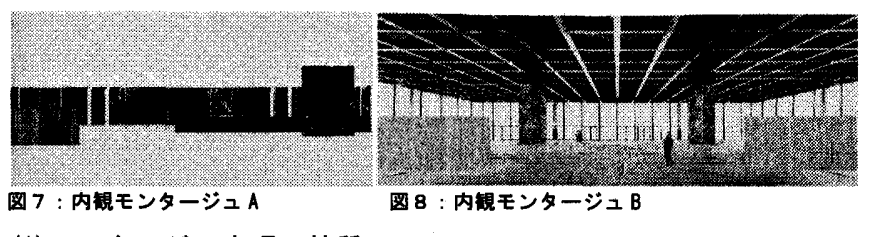

(1)モンタージュ表現の特質

(1)透視図法の特質

i）内観モンタージュA

内観モンタージュの大半を占める内観モンタージュ A はその背景 が単線で描かれた透視図であり、25点が作成されている。これらの

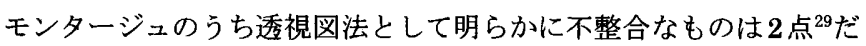
けである。また 25 点中 24 点が一消点透視図法で描かれており、二 消点透視図法で描かれたものは 1 点しか存在しない。ドイツ期に作 成された単線による内観透視図 10 点のうち 3 点は二消点透視図法で 
衰 4 : 内観モンタージュの特篰

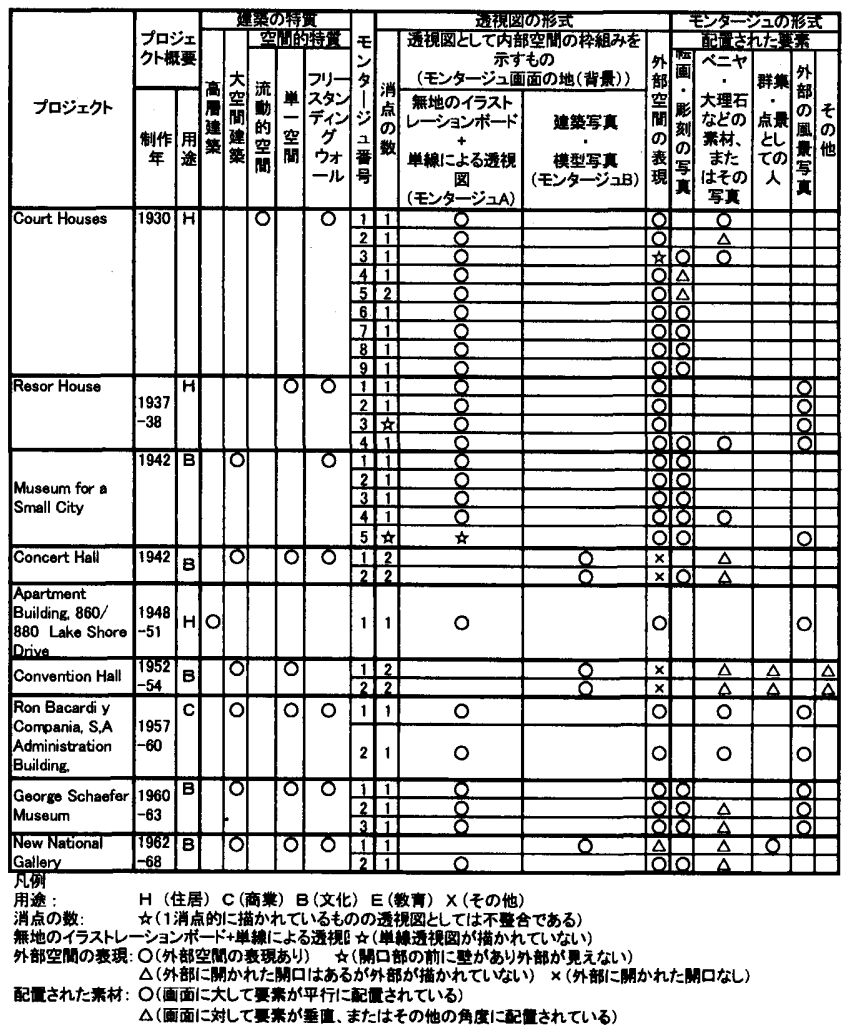

表 5 : 内钼透視图のハンドドローイングの特施

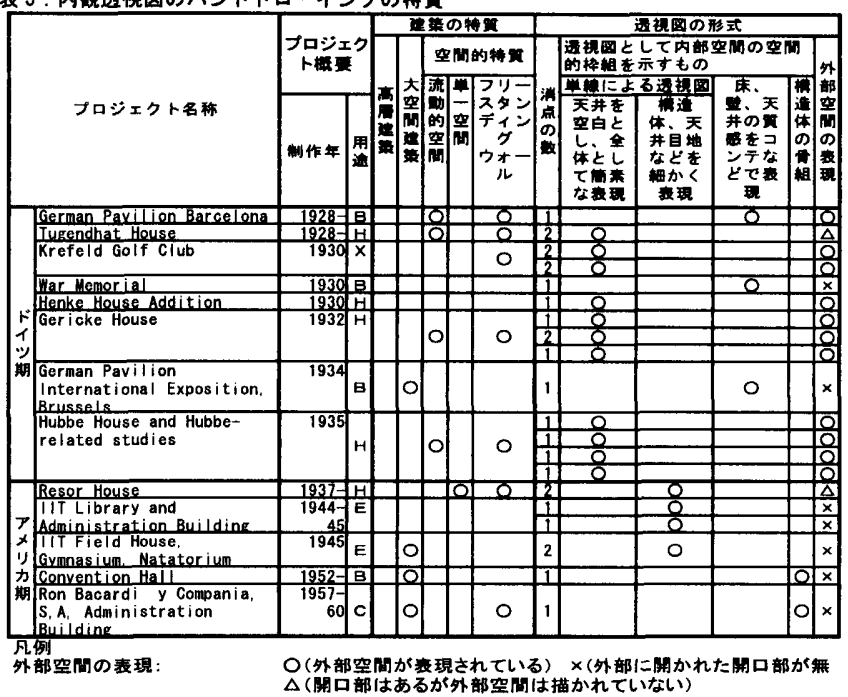

あり、このことからも内観モンタージュAの特異性が明らかになっ ている。一消点透視図法の透視図は一般的に奥行きを強調するのに 適した手法であるといわれている ${ }^{30}$ が、同時に、一消点透視図法で 画面に平行に要素を配置した場合、要素の形状は消点との位置関係 に影響を受けないという特質も有している(図 7)。一消点透視図法 のモンタージュのうち、素材がこのように配置されているものは、 24 点中 18 点と $75 \%$ を占めている。

ii）内観モンタージュ B

内観モンタージュBにおいては、内部空間の透視図的枠組みは背 景となる写真によって決まるが、 5 点中一消点透視図法で描かれて いるものはニューナショナルギャラリーの1点のみである。また、 その空間表現は内観モンタージュAのように輪郭線のみで示される
のではなく、写真によって面的に空間的広がりや奥行きが表現され ている点がこれらのモンタージュの特質といえるであろう。

\section{(2)モンタージュ表現の特質}

\section{i）内観モンタージュA}

内観モンタージュの大半を占める内観モンタージュ A は、ハンド ドローイングで描かれた内部空間の透視図に絵画・彫刻・風景の写 真、ベニヤや大理石の写真などがモンタージュされている。すべて のモンタージュが外部に開かれたフルハイトの窓を持ち、外部の風 景はハンドドローイングや写真によって表現されている。

ベニヤ、大理石の写真などのモンタージュ素材はフリースタンデ イングウォールとして配置されているが、モンタージュされた要素 は素材の小口が表現されておらず、厚みのない矩形として表現され ている。絵画はニューナショナルギャラリーの一例をのぞくと、壁 にかけられることはなく、自立した壁として表現されるか宙に浮い た存在のように描かれている。また、絵画の多くが実際の作品の大 きさよりはるかに大きく拡大されており、ブラックの絵画にいたっ ては、拡大された断片が配置されている(図 9)。これらのモンタージ ユ素材は透視図内での前後関係などによって奥行き感などの表情の 調整が加えられることなく、そのまま透視図に配置されている。背 景より明らかに豊かな表情を持った素材が配置され、これらの素材 が画面内での前後関係に関俰なく視覚的に浮き上がって見えるため に、内観モンタージュAは一つの空間表現としてみた場合、ハンド ドローイングの透視図と比べて透視図が描き出す空閒の奥行き関係 が暧昧になっている3!。また素材が画面に平行に配置されている場 合は、前述のように配直された要素の形態が消点に向かって収束し ないため、透視図としての空間表現はさらに曖昧になる。こういっ た手法によってモンタージュAの透視図は、各要素の位置が把握で きる透視図としての奥行き感ではなく、描かれた空間内におけるモ ンタージュされた要素の浮遊感が表現されていると考えられる。

空から見える外部空間はハンドドローイングで表現されたモンタ ージュ 14 点と、写真で表現されたモンタージュ 11 点が存在する。 ハンドドローイングで表現されている外部は内部空間の延長のよう に表現された近景のみであり、一方、写真で表現されている空間は 中景・遠景のみである。空際の若干の犬走り空間を除き、外部空間 がハンドドローイングと写真の両方によって表現されることは無い。 また、ハンドドローイングにおいて遠景が表現されることもない。 外部空間を表現する写真は、表 6 のように 11 点のうち 2 点は透視 図によって描き出される空間の奥行きを意図的に無視した水盤や緑 の断片写真である(図 7)。また残りの風景写真 9 点のうち、計画され た敷地からの風景またはそれに類する風景が選択されているものは わずかに 3 点のみであり、それ以外は敷地条件とは無関係な雄大な 自然などの視覚的なスペクタクル（図 10）が配置されている。

このようなモンタージュAの特質、モンタージュされた素材の厚 みを表現せず、浮遊感を生み出す配置手法、そして、外部空間とし て表現されたイメージにおける実際の外部状況を反映していないイ メージの選択などから、モンタージュAは実際に作られる内部空間 が実際にどのように見えるかという絵画としての建築空間の視覚的 再現を意図したものではなく、むしろフリースタンディングウォー ルとして配置された内部の要素の可動性や、内部空間と外部空間の 不連続性といった理念的な側面を表現していると考えられる。 


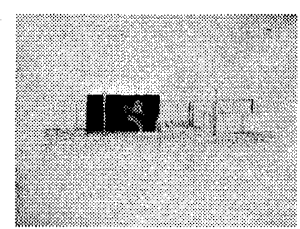

図 9 : コートハウス竍画

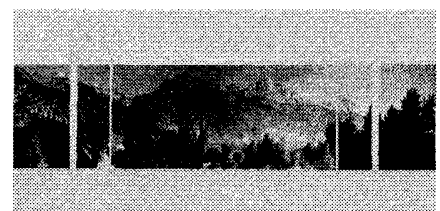

図 $10:$ レザー郳

表6：内穓モンタージュAにおける外部風暴の写真の特留

\begin{tabular}{|c|c|c|c|c|c|c|c|}
\hline \multirow{2}{*}{ プロジェクト } & \multirow{2}{*}{ 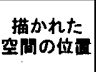 } & \multirow{2}{*}{ 消 } & \multirow{2}{*}{$\begin{array}{c}\text { 外部空間 } \\
\text { の位倍 }\end{array}$} & \multicolumn{4}{|c|}{ 外部衰現 } \\
\hline & & & & 㮔别 & 位睘 & 表現 & 内部之 \\
\hline \multirow{4}{*}{ Resor House } & \multirow{4}{*}{$\begin{array}{c}\text { 20陵 } \\
\text { (川の上) }\end{array}$} & 1 & 奥 & 写真 & 中易 & 実際の敖地からの風量 & 0 \\
\hline & & 1 & 奥 & 写真 & 薄基 & 雄大な山山並子小 & $x$ \\
\hline & & $1 *$ & 奥 & 直蒖 & 蒿悬 & 隻大な山並み & $x$ \\
\hline & & 1 & 奥 & 直真 & 盍党 & 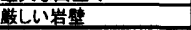 & $\bar{x}$ \\
\hline Museum for a Small City & \multirow{2}{*}{ 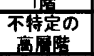 } & $1 *$ & 奥 & 写我 & 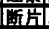 & 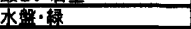 & $x \times$ \\
\hline \multirow{3}{*}{$\begin{array}{c}\text { Apartment Building, 860/ } \\
880 \text { Lake Shore Drive } \\
\text { Ron Bacardi y Gompania, } \\
\text { S,A, Administration } \\
\text { Building }\end{array}$} & & 1 & 奥 右手 & 写共 & 遭量 & シカゴの街並 & 0 \\
\hline & \multirow[b]{2}{*}{ 1擆 } & 1 & 奥 & 写空 & 㗐是 & 田国地带 & 0 \\
\hline & & 1 & 奥 & 写基 & 断片 & 䜌の断片 & $x \times$ \\
\hline \multirow{3}{*}{ George Schaefer Museum } & \multirow{3}{*}{ 1睹 } & 1 & 奥 & 写县 & 触 & 湖鮮の鳥㗨 & $x$ \\
\hline & & 1 & 奥 & 察言 & & 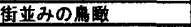 & $x$ \\
\hline & & 1 & 奥〜右杀 & 窎章 & 黄隹 & 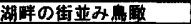 & $x$ \\
\hline
\end{tabular}

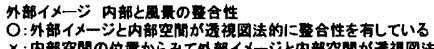

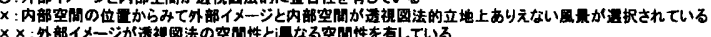

ii）内観モンタージュB

内観モンタージュ $\mathrm{B}$ の二消点透視図法のモンタージュ 3 点は二消 点透視図特有の空間的広がりのある表現となっている。一消点透視 図法のニューナショナルギャラリーは天井がその空間的棹組、奥行 き感を強く表現しており、要素はシンメトリに配置され、壁は厚み があるものとして表現されている(図 8)。背景となる建勧の写真が 生み出す透視図法上の空間的枠組みが画面を支配しており、内部に 配置される素材も背景の空間的枠組みに則って配置されている。ま た素材の表面のテクスチャーが背景と大きく異ならないため、その 画面の統一性は維持され、その表現も基本的には再現的なものであ る。これらのことから、モンタージュ Bの表現の中心が空間を成立 させている建築本体の持つ、力強さや巨大さといった感覚的な側面 を表現していることが示唆される。

\section{（2）内観透視図のドイツ期とアメリカ期の比較}

アメリカ期のミースの内部空間は7プロジェクトのために 25 点が 内観モンタージュAによって、3プロジェクトのために 5 点が内観 モンタージュBによって、3プロジェクトのために 3 点が単線によ るハンドドローイング（図 12）（構造体の骨組み表現などを除く） による透視図として表現されている。一专イ゙イツ期では内観モンタ ージュは作成されず、内部空間は 11 点の単線によるハンドドローイ ング（図 11）と 3 点の建築要素の素材感を表現したハンドドローイ ングによる透視図で表現されている。表 5 のようにハンドドローイ ングにおいても、ドイツ期とアメリカ期はその表現が変化している ことから、ここでは、内観モンタージュ、ハンドドローイングを含 めた内観透視図の表現についてドイツ期とアメリカ期を比較する。

ドイツ期の単線によるハンドドローイングは、素材の質感などを 表現することなく、単線による輪郭線だけで空間的広がりを表現し ており（図 11）、素材感を表現したハンドドローイングは素材の質 感をコンテなどで表現し、その面的な表現によって空間的広がりを

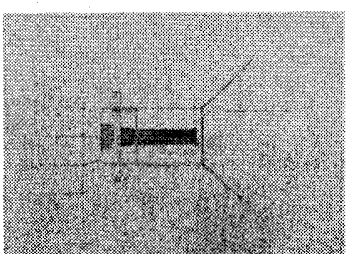

因11: フッベ邸の内镜透視図

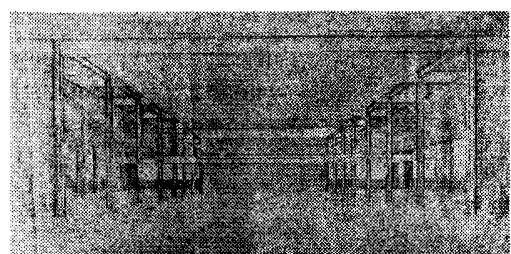

图 12 : I. I. I. 图書館の内镜透視图
表現している。アメリカ期において、内部空間を単線で透視図とし て描いたものはモンタージュAの背景とハンドドローイングによる 内観透視図であるが、モンタージュAにおいても、前述のとおり外 部がハンドドローイングで表現されたモンタージュと、写真で表現 されたモンタージュが存在し、1940 年前後においては、両方のモン タージュが作成されているが、1940 年代後半以降は、作成された 7 点の内観モンタージュAのうち、外部がハンドドローイングで表現 されたモンタージュは1点のみである。一方、アメリカ期のハンド ドローイングは、単線での表現ながら、鉄骨の仕ロやパネルの割付 などを詳細に表現しており、モンタージュAの背景とは異なる表現 となっている（図 12）。単線ドローイングだけを取り出した場合、 輸郭線によって空間を表現している点などドイツ期のハンドドロー イングと内観モンタージュAはその表現において類似しているが、 前述のように作品全体としてみた場合、その空間表現は必ずしも一 致しない。このため、ドイツ期のハンドドローイングがモンタージ ュに発展する形でモンタージュ A が生み出され、その手法を特化さ せるなかで、独自の表現手法を獲得したと考えられる。また、モン タージュAの表現の特化と同時に、ハンドドローイングはより詳細 を表現する手法へと特化していたと考えられる。一方、ドイツ期に 見られた要素の質感をコンテなどで表現したハンドドローイングは 類似する手法をアメリカ期では確認できなかった。アメリカ期に作 成された内観透視図のうち、モンタージュBでは、写真によって空 間を構成する要素の質感は表現されている。

（3）考察 : 空間表現としての内镜モンタージュ

表 4、5 のように、内観モンタージュAが作成されたプロジェクト の大半がその空間的特質として流動的空間、単一空間のいずれかを 有している。ミースの空閒特性が流動的空間から単一空間へと移行 するのは 1940 年代といわれており、モンタージュにおいてもこのこ とは反映されている。また、内観モンタージュAの表現上の特質と して、外部表現がハンドドローイングで描かれているか、写真で描 かれているかといら二つの特質が存在するが、この特質はほぼ、空 間の特質と一致する。つまり、流動的空間を描いたモンタージュは 外部がハンドドローイングで表現されており、単一空間を描いたモ ンタージュでは外部は写真で表現されている。特に、流動的空間と 単一空間の空間特質の転換期のプロジェクトとされる ${ }^{32}$ 小都市の美 術館が、ハンドドローイングで外部を描かれたモンタージュと写真 によって外部が表現されたモンタージュの両方を有していることは、 空間的特質とモンタージュ表現の関保性を示唆している。

前節に打いて、内镅モンタージュA とその表現方法において連続 性を有すると指摘したドイツ期の単線によるハンドドローイングの 大半も流動的空間の特質有するプロジェクトのために作成されてい る。内観モンタージュAのハンドドローイングによって表現された 外部空間はドイツ期のハンドドローイングの外部表現とは異なり、 敷地外部の環境は描かれていないが、内外の連続性は維持されてい る。一方、単一空間の特質を有するプロジェクトのモンタージュは 全て外部が写真で表現されており、前述のように、そのイメージの 大半が実際の周辺環境を反映したものではない。このことから、モ ンタージュ表現に限定した場合、その描かれる空間が流動的空間か ら単一空間へと移行するのと連動するように外部空間の表現方法が 変化したといらことができる。一方、内镅モンタージュ B が作成さ 
れたプロジェクトはすべてメガストラクチャーによって単一空間を 表現しており、メガストラクチャーの巨大さや、カ強さが再現的に 表現されている。しかし、これらのモンタージュにおいても外部空 間は表現されていない(図 8)。

\section{6 章 むすび}

今まで単に一括して捉えられていたミースのモンタージュをその 表現手法によって分類を行い、モンタージュの表現の特質に応じて、 その表現される内容が異なることが明らかになったと考えられる。

ミースのモンタージュは、ドイツ期は主に外観モンタージュが作 成され、アメリカ期では、主に内観モンタージュが作成されている。 つまり、モンタージュの表現において、ドイツ期の外観モンタージ ュでは街並みという周辺環境との関係性を重視したモンタージュが 作成されていたのに対して、アメリカ期では、外観モンタージュが 1 点しか作成されず、その表現は周辺環境との関俰よりも建築単体 にその表現の中心が移行している。一方、アメリカ期の大半を占め る内観モンタージュにおいては、内部から見える外部空間は、内部 空間の延長としての中庭や前庭にとどまり、その外部、敷地外の罢 境は描かれないか、実際の周辺環境とは異なるイメージの写真が選 択されている。このことからアメリカ期のモンタージュはドイツ期 と比べて、周辺環境との関倸性を重視ていないか、もしくは周辺環 境から切り離した表現を行っていると考え、内部空間の特質を表現 していると考えられる。

次稿では、それぞれのモンタージュの特質を踏まえて、ミースの モンタージュにおける空間表現について内外空間の表現という観点 からより踏み込んだ考察を行う。

注

デヴィット・スペース、(平野暂行訳)「ミース・ファン・デル・ローエ」鹿岛出版全 1988 年、p. 156

21976 年にマンフレッド・タフーリとフランシス・タル・コーの「Modern Archi tecture によって提示されたミースの空間楧成法のメタファーとしてモンタージュを考えると いら視点はその代表的なものである。(Manfredo Tafuri / Francesco Dal Co, (Robert Erich Wolf 訳) PModern Architecture 1] Rizzoli 1986, p.136)

3 ミースのモンタージュに言及した既往研究として以下の論文を产照した。

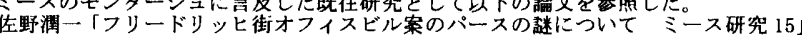
旦本建築学会大会学術講演梗概集 1997 年 9 月, p. 403

杉本俊多、永田居太郎、「ミース・ファン・デル・ローエの 1920 年代高尿建策案 $\mathrm{co}$ 再表現を通しての研究」日本建築学会計画系論文集、第 493 号

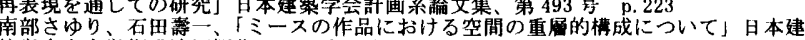
策学会大会学術講演梗概集、2001 年 9 月 0.579

國分大輔、松本样昌、田路貴浩、「ミース・フコン・デル・ローエの透視図とモンタ ージュについて (1)<主題〉の分析」日本建築学会大会学術講演梗概集 2004 年 8 月、 p. 775

4 Andres Lepik, 「Mies and Photomontage, 1910-38」『Mies in Berlin』The Museum

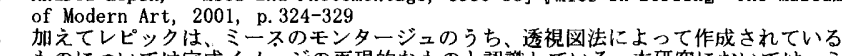
ものについては完成イメージの再現的なものと認識している。本研究においては、ミ 一不透視図モンタージュが建築空間の絵画的再現を意図したものであるかをつの

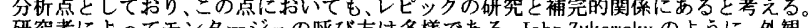

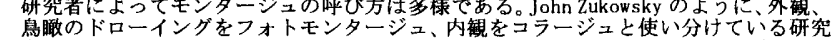
者がいる一方で、Franz Schulzeの上うに二つに猃文の間で同じドローイングを別の 手び方で用いている例も見出せる。研究者のほとんどが、モンタージュの呼び方につ いて特に説明的なことを述心ていないが、Andres Lepik は「Mies and Photomontage ぶ理由を、コラ゙ージュが画面の統一性を破壊するのに対して、モンタージュが統一さ れた画面の形式を保持するためとしている。

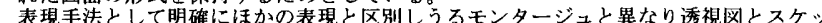

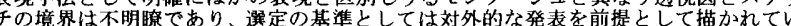

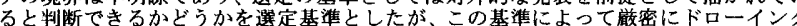

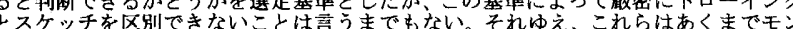
タージュのプレぜンテーション手法としての特性を理解するための参考資料として位 置付けている。

8 モンタージュは以下の資料から採取した

(1)Arthur Drexler, 『Ludwig Mies van der Rohe』George Braziller, Inc. 1960 (2) Philip C. Johnson 『Mies van der Rohe』 The Museum of Modern Art, 1978 (Third edition)

(3)Peter Cater, 『Mies van der Rohe at work』 Phaidon, 1974

(4) Wolf Tegethoff, 『Mies van der Rohe The Villas and Country Houses』 The Museun of Modern Art, 1985 Franz Schulze, 『Mies van der Rohe A Critical Biography』 The University of Chicago Press, 1985

(6) Mies van der Rohe Archive vol. 1-20, The Museum of Modern Art, 1992 (7) Jean-Louis Cohnen, 『Mies van der Rohe』. Hazan, 1994

8) Maritz Vandenberg, TNew National Gallery, Berlin』 Phaidon, 1998

(9)Terrence Riley and Barry Bergdoll ed., 『Mies in Berlin』, The Museum of Modern rt, 200 WPhyllis Lambert ed. 『Mies in America』 Canadian Centre for Architecture,
(11)八東はじめ『ミースという神話、ユニバーサルスペースの起源』彰国社，2001 調查対象から抽出したそンタージュは 57 点。このうち、ベルリン建策展のための内 観透視图のモンタージュは展示会の会場設営を撗いたものであり明らかにほかのモ 多一シュとは様相をことにするため对象から除外した。また、実際の敷地に原寸大

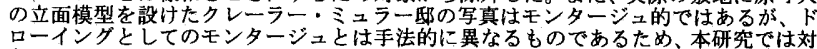
ローイングと

10 象とシタージュの作成年についてはプロジェクトの計画年を採用しているが、後年にモ シタージュが作成されたという指摘があるものについてはそれを採用した。1930年代 のコートハウス計画はドローインクの作成時期とプロシェクト計画時期の閒に時間的 ズレが存在する事がわかっており、この場合はモンタージュが作成された時期を制作 年としている(Terence Riley, 「From Bauhaus to Court-House] from『Mies in Berlin』 p. 331)

法第一回国際ダダフェア1920 年のオープニングに参加しており、このこと

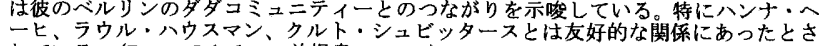
れている。(Franz Schulze, 前揭書, p. 104)

12 たとえば、八束はじめ氏はミースのモシタージュ手法の愛好をダダからの影響に起因 しているとしている (八束住じめ, 前揭書, p. 146)

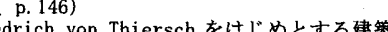
家たちはコンペティションの提出物として、ドーイングを奏祭の予定地の写真に重

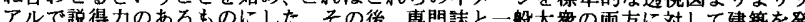

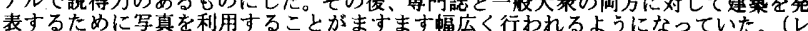

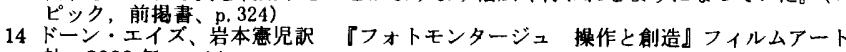
社、2000 年、 p. 14

15 ジークフリート・ギーディオンは、「空間・時閒・建築」において前者をダダイスト、 ロシア構成主義者によって生み出されたモンタージュ特有の非透視図法的な表現とし、

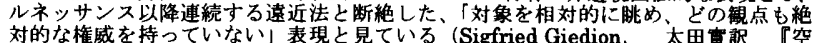
対的な権威を持っていない」表現と見ている (Sigfried Giedion, 太田實訳『空 間・時間・建策』丸善株式会社 1974 年 p.511)

16 たとえは、シュツットガルトのバンクビルディングの計画では、ほかの建築家による ミースのモンタージュと同じアングルのモンタージュが確認されている。

17 Adrian Sudhalter 「Bismarck Monument Project, Bingen, 1910」 『Mies in Berlin』

18 た. 158 だし、1960年のドレクスラーによるミースの作品集などではこのモンタージュやド

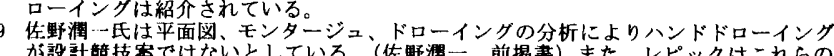

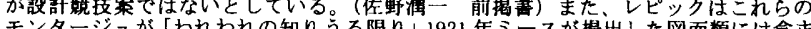

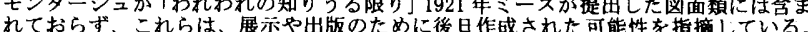

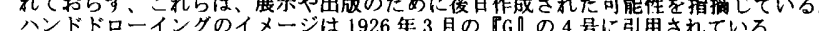

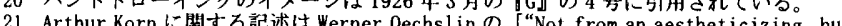
from a general and Determinism: A Plea for Value-Criteria in Architecture」(Mies in America, p. 38) より引用した。

22 Terrence Riley and Barry Bergdoll ed., TMies in Berlin』. The Museum of Modern Art, 2001, p. 249 の图面注より

23 Lepik, 前揭萧 p. 327

Detlef Martins 「Architectures of Becoming: Mies van der Rohe and the Avant-Garde) Mies in Berlin』 The Museum of Modern Art, 2001, p. 107

24 コンサートホールのモンタージュは1.1.T.の学生であったポール・カンパーニャ(Paul Campagna) が 1941 年に作成した卒業設計のためのモンタージュがベースとなってお り、以後、ミースは同榛の課題を学生に課したといわれている。また都市の美術館 のモンタージュは、やはり 1941年、当時I. I.T.の学生であったジョージ・ダンフォ

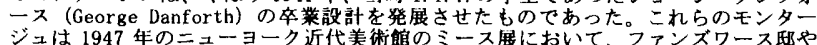

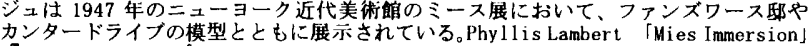
『Mies in America』p. 423-429

25 Peter Carter Mies van der Rohe at Hork の作品リストをべースとして、Mies va der Rohe Archiveをリストを補完するものとして使用した。また、イシテリアおよび、 展筧会の設学は除外した。

26 侉野润一 前揭書、レピック, 前指莒, p. 326

このプロジェクトは作品年表には掦載されているものの、作品集に揭载されていない

モンタージュ・ドローインクが作成されたプロジェクトの空閒特質を表現する言集を 『Mies van der Rohe Archive vol.1-20】. The Museum of Modern Art, 1992 [ $\neg$ ロジククのコメントは Franz Schulze

詊伀シース・ファン・デル・ローエ』Franz Schulze 瀑村明訳 鹿岛出版会 1987 年から抽出

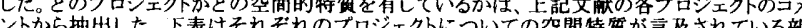
分归不化したの

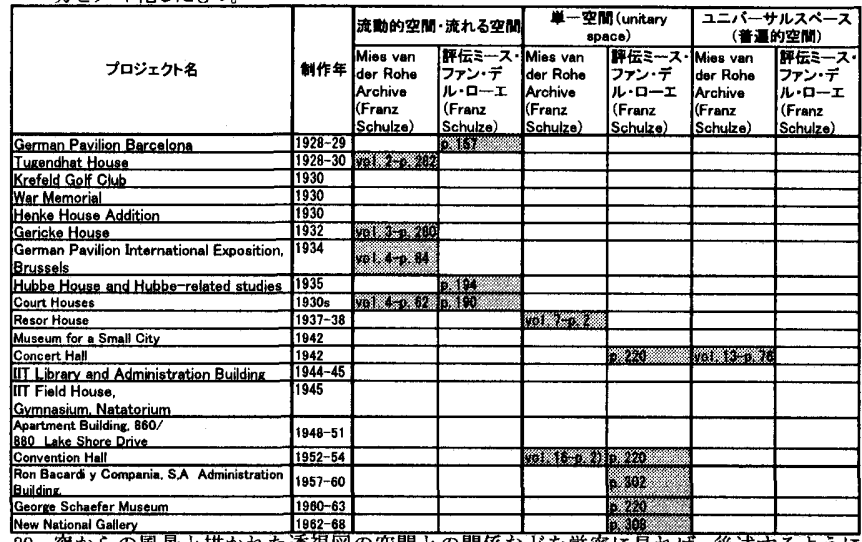

29 空からの風景と描かれた透視図の空間との関係な

透視図法的に矛盾したモンタージュは7点となる

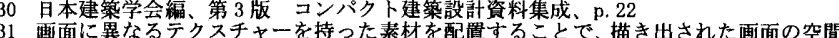

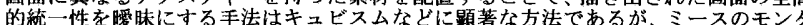
一シュに拟ては、タージュされた素材は断片的でありながら透視図を破綰

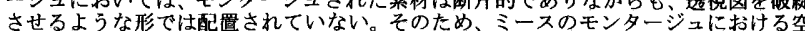
間的統一性の曖晰化はキュビスムやダダのモシタージュとは、その質や程度が異なる ものであるといえるであろう。

32 Schulze, 前揭書 p. 230

（2005年11月10日原稿受理，2006年 5 月 22 日採用決定） 